JURNAL PARIWISATA BUDAYA, VOLUME 3, NOMER 2, TAHUN 2018

HALAMAN 15-23

\title{
Strategi Pengembangan Pariwisata Berbasis Budaya di Desa Selumbung, Karangasem
}

M. Agus Sutiarso, K.T. Pratiwi Arcana, N.P. Eka Juliantari, I.M. Bayu Gunantara Sekolah Tinggi Pariwisata Bali Internasional, Denpasar

\begin{abstract}
Selumbung Village is one of the villages that is directed to be developed as a tourist village in Karangasem regency. Culture-based tourism development in this village is expected to provide benefits to the community if properly managed and planned. This study aims to get a recommendation for the strategic plan of cultural-based tourism development in the village of Selumbung. The analytical method used in this study includes descriptive analysis which is assisted by the SWOT analysis method to determine the development strategy plan. The results showed that the priority of the culturebased tourism development strategy plan in the village of Selumbung was to develop tourism products, improve management and marketing.
\end{abstract}

Keywords: cultural tourism, village tourism, strategic plan

\section{Pendahuluan}

Dalam kebijakan Pemerintah Provinsi Bali, tiap-tiap wilayah memiliki kesempatan sama untuk berkembang. Wilayah yang berpotensi mengembangkan desa wisata adalah Kabupaten Karangasem. Visi Dinas Kebudayaan dan Pariwisata Kabupaten Karangasem tahun 2017 yaitu, terwujudnya Karangasem sebagai daerah tujuan wisata budaya dengan melaksanakan pembinaan dan pengembangan pariwisata budaya secara terarah, terencana dan terpadu. Maka desa wisata di Kabupaten Karangasem cenderung berkembang ke arah pengembangan pariwisata berbasis budaya, misalnya Desa Tenganan, Desa Jasri, Desa Dukuh, dan Desa Bungaya.

Dalam perkembangannya, kepariwisataan Kabupaten Karangasem telah memberikan kontribusi pendapatan bagi daerah yang bersumber dari pajak hotel dan restoran, serta retribusi sektor pariwisata (destinasi). Dari sisi perolehan pendapatan daerah, sektor pariwisata di Kabupaten Karangasem menjadi salah satu unggulan, dengan menempati posisi kedua setelah pertambangan mineral bukan logam dan batuan (Dinas Kebudayaan dan Pariwisata Kabupaten Karangasem, 2016).

Desa Selumbung adalah desa wisata yang dikembangkan sejak tahun 2014 (SK Bupati Nomor 658/HK/2014). Potensi desa ini adalah potensi wisata alam air terjun, persawahan, dan sungai. Potensi wisata budaya seperti upacara ngusaba puseh, kesenian daratan, dan wayang wong. Ada juga potensi wisata ekonomi 
kreatif seperti peternakan lebah madu dan produksi virgin coconut oil (VCO). Meskipun memiliki potensi wisata yang beragam, nyatanya dukungan akses dan fasilitas kepariwisataan desa masih belum maksimal. Masyarakat juga belum memahami potensi desa dan sistem pengelolaan kepariwisataan yang belum sinergis antar elemen pemangku kepentingan.

Berdasarkan latar belakang itu, dapat dirumuskan masalah berupa bentuk produk, analisis faktor internal dan eksternal, serta strategi pengembangannya. Penelitian ini berlokasi di Desa Selumbung, Kecamatan Manggis, Kabupaten Karangasem, Provinsi Bali. Dalam pengumpulan data, digunakan observasi, kuesioner, wawancara, diskusi kelompok terarah, dan studi dokumen. Data dianalisis secara analisis deskriptif kualitatif (Sugiyono, 2003), dan analisis SWOT (Strenght, Weakness, Opportunity, and Threat).

\section{Pembahasan}

Analisis faktor internal dari pariwisata di Desa Selumbung dapat diidentifikasi berdasarkan analisis visi, misi Desa Selumbung dan analisis existing management. Sementara analisis faktor eksternal dari pariwisata di Desa Selumbung dapat diidentifikasi berdasarkan analisis politik, ekonomi, sosial, dan teknologi. Visi dari Desa Selumbung adalah "Kebersamaan dalam Membangun Demi Desa Selumbung yang Lebih Maju Sejahtera dan Mandiri", sedangkan misi dari desa ini adalah, 1) Bersama masyarakat memperkuat kelembagaan desa yang ada sehingga dapat melayani masyarakat secara optimal; 2) Bersama masyarakat dan kelembagaan desa menyelenggarakan pemerintahan dan melaksanakan pembangunan yang partisipatif; 3) Bersama masyarakat dan kelembagaan desa dalam mewujudkan Desa Selumbung yang aman, tentram, dan damai; 4) Bersama masyarakat dan kelembagaan desa memberdayakan masyarakat untuk meningkatkan kesejahteraan masyarakat.

Kondisi pengelolaan kepariwisataan desa (existing management) telah diidentifikasi berdasarkan empat kategori yaitu perencanaan (planning), pengorganisasian (organizing), pelaksanaan (actuating), dan pengawasan (controlling). Dalam pelaksanaan program-program pengembangan pariwisata di Desa Selumbung, pemerintah desa menyerahkan tanggung jawab sepenuhnya pada Pokdarwis. Pokdarwis diharapkan mampu mengajak masyarakat untuk berpartisipasi aktif dalam pengembangan pariwisata di desa. Sejauh ini program yang telah dilaksanakan oleh pokdarwis adalah perbaikan fasilitas dan akses menuju objek wisata Air Terjun Yeh Labuh. Perbaikan yang dilakukan adalah dengan membangun jembatan baru yang lebih kokoh menuju air terjun, penghijauan, dan pembentukan jalur trekking. Program-program yang dilakukan seringkali mengalami hambatan dalam hal pengadaan dana, karena dari desa belum memberikan anggaran khusus untuk pengembangan pariwisata.

Masyarakat Desa Selumbung pun kesulitan untuk ikut terlibat dalam pengembangan pariwisata, khususnya pariwisata berbasis budaya karena keterbatasan dalam pemahaman budaya setempat ataupun keahlian berbahasa asing. Pemahaman terkait budaya lokal hanya diketaui oleh para pemangku adat (kelian) dan seringkali tidak dapat disosialisasikan dengan baik kepada masyarakat karena anggapan bahwa pengetahuan tersebut bersifat sakral atau tabu. 
Pengembangan pariwisata berbasis budaya di Desa Selumbung saat ini masih belum konsisten karena fungsi pengawasan yang seharusnya dilakukan oleh para pemangku kepentingan tidak dijalankan dengan baik. Tidak ada pelaporan kegiatan kepada desa maupun pemerintah kabupaten, mengakibatkan terjadinya pencapaian yang telah didapat tidak tercatat dengan baik. Jumlah wisatawan yang berkunjung dan alur retribusi juga belum dicatat dengan baik sehingga sering menimbulkan konflik kepentingan.

Kondisi sosial masyarakat di Desa Selumbung saat ini sangat kondusif. Berdasarkan keterangan dari Kepala Bintara Pembina Desa dan Perlindungan Masyarakat Desa Selumbung diketahui bahwa tindak kriminalitas di desa ini sangat rendah. Selain itu, masyarakat Desa Selumbung sangat ramah terhadap pendatang dan saling menghargai satu sama lain. Namun, masyarakat seringkali mengalami kesulitan dalam berkomunikasi, terutama bila menghadapi wisatawan mancanegara. Sementara secara teknologi, masyarakat desa sudah sangat terbuka dengan adanya globalisasi.

Berdasarkan analisis visi, misi, kondisi existing management, dan kondisi politik, ekonomi, sosial, serta teknologi terkait pengembangan daya tarik wisata di Desa Selumbung, Kabupaten Karangasem, telah diidentifikasi faktor internal (Kekuatan dan Kelemahan) dan eksternal (Peluang dan Ancaman) pengembangan wisata desa sebagai berikut:

a) Kekuatan (S), Desa Selumbung memiliki potensi untuk dikembangkan menjadi produk wisata berbasis budaya, Desa Selumbung ditetapkan sebagai Desa Wisata sejak tahun 2014, melalui SK Bupati Karangasem, Desa Selumbung mendapat anugerah Desa Wisata Award 2017 dari Pemprov Bali, Desa Selumbung memiliki Kelompok Sadar Wisata, masyarakat setempat sangat terbuka terhadap adanya pengembangan pariwisata, Desa Selumbung memiliki fasilitas wisata yang memadai, seperti homestay dan lahan parkir yang luas, Desa Selumbung merupakan desa dengan tingkat keamanan yang baik, Desa Selumbung memiliki awig-awig (aturan adat) yang mendukung pengembangan desa wisata, dan tersedia penunjuk arah ke lokasi daya tarik wisata.

b) Kelemahan (W), Belum memiliki sumber daya manusia yang kompeten dan professional di bidang pariwisata, tidak semua aktifitas budaya dapat dikomersialisasikan/dijual untuk kebutuhan pariwisata, keterbatasan dana untuk pengembangan fasilitas wisata dan pelatihan sumber daya manusia, Pokdarwis belum memiliki sistem pengelolaan pariwisata yang terencana dan sistematis, belum memiliki regulasi resmi yang mengatur kepariwisataan desa, belum memiliki sistem pengelolaan sampah plastik, belum memiliki standar higienis untuk layanan makan dan minum, jaringan komunikasi (internet) masih terbatas untuk beberapa provider, belum tersedia media yang dapat mendukung interpretasi wisatawan terhadap daya tarik wisata di Desa Selumbung (brosur, information center, guide), jumlah kunjungan wisatawan masih sedikit, dan belum ada paket wisata dari biro perjalanan/travel agent yang menawarkan aktifitas di Desa Selumbung.

c) Peluang $(\mathrm{O})$, visi dan misi Disbudpar Kabupaten Karangasem, mendukung perkembangan produk wisata berbasis budaya, peningkatan jumlah kunjungan 
wisatawan ke Kabupaten Karangasem periode Januari-Desember 2016, pelestarian lingkungan fisik dan budaya sebagai dampak positif pengembangan pariwisata, peningkatan jumlah pendapatan dan ketersediaan lapangan pekerjaan, kemajuan teknologi informasi dan komunikasi.

d) Ancaman (T), perubahan lingkungan fisik (pencemaran, limbah, sampah, dan polusi), bencana alam (gempa bumi, gunung meletus, banjir, tanah longsor), muncul destinasi (desa wisata) lain yang menawarkan produk serupa, terjadinya eksploitasi budaya secara berlebihan, sehingga tidak ada batasan antara aktifitas sakral dan seni pertunjukan, dan masyarakat dapat dengan mudah terpengaruh oleh budaya asing yang tidak sesuai dengan norma/adat setempat.

\section{Analisis SWOT}

Dari identifikasi faktor internal dan eksternal tersebut, maka dapat disusun strategi yang disajikan dalam matriks yang menghasilkan empat set kemungkinan alternatif strategi yaitu sebagai berikut:

1) Strategi S-O, yaitu mendukung strategi agresif. Strategi yang diterapkan adalah mendukung kebijakan pertumbuhan yang agresif (growth oriented strategy) dengan cara:

a) Memanfatkan Desa Selumbung yang telah ditetapkan sebagai desa wisata melalui SK Bupati Karangasem Tahun 2015 untuk dapat meningkatkan tingkat kunjungan wisatawan yang tertarik terhadap produk wisata berbasis budaya melalui manajemen pemasaran yang konsisten.

b) Memanfaatkan penghargaan (Desa Wisata Award Kategori Silver) yang telah didapat untuk meningkatkan brand image Desa Selumbung di mata wisatawan dan memotivasi masyarakat setempat untuk mengelola sumber daya pariwisata yang dimiliki, melalui pelatihan (bahasa asing, keahlian pariwisata, pengetahuan tentang budaya) maupun pembinaan oleh Dinas Pariwisata, kalangan akademisi, dan swasta.

c) Memanfaatkan Kelompok Sadar Wisata (Pokdarwis) untuk merencanakan, mengatur, dan mengawasi pengelolaan sumber daya pariwisata desa melalui penetapan peraturan pembangunan usaha wisata, pengembangan aktifitas, dan alur pendistribusian retribusi serta pembagiannya.

d) Memanfaatkan kemajuan teknologi untuk mendukung layanan kepariwisataan desa (dalam bentuk brosur, website khusus produk wisata, calendar of events, dan buku panduan wisata) sehingga dapat mendukung interpretasi wisatawan terhadap produk wisata berbasis budaya yang dimiliki oleh Desa Selumbung.

2) Strategi S-T, yaitu mendukung strategi diversifikasi. Strategi yang diterapkan adalah menggunakan kekuatan yang dimiliki atraksi dan daya tarik wisata untuk memanfaatkan peluang jangka panjang (produk/pasar) dengan cara:

a) Memanfaatkan potensi wisata di Desa Selumbung untuk dapat dikembangkan sebagai produk wisata berbasis budaya, dengan 
mengembangkan aktifitas wisata berbasis budaya yang nantinya wisatawan akan didampingi untuk mengelilingi desa, sehingga dapat mendukung interpretasi wisatawan tersebut dalam menikmati aktifitas keseharian masyarakat seperti menenun, menganyam, mengukir, bertani, berternak, aktifitas keagamaan, seni tari, dan tabuh.

b) Memanfaatkan produk wisata budaya yang dimiliki oleh Desa Selumbung untuk dijadikan daya tarik bagi wisatawan dengan membuat imitasi/duplikat dari kegiatan budaya setempat, hasil dari imitasi budaya tersebut dapat dirancang ke dalam time schedule yang bisa dipilih oleh wisatawan ataupun travel agent atau dapat juga melalui pemesanan (taylor made tour).

c) Memanfaatkan kearifan lokal masyarakat yang tertuang dalam awigawig (aturan adat setempat) untuk meminimalisasi terjadinya eksploitasi sumber daya alam maupun budaya yang berlebihan akibat dari pariwisata, serta mengajak masyarakat untuk bersama-sama menjaga kebersihan dan mengurangi pencemaran akibat dari sampah plastik mulai dari rumah tangga di masing-masing banjar.

d) Memanfaatkan tokoh-tokoh masyarakat adat untuk dapat berperan aktif dalam pengembangan produk wisata berbasis budaya di Desa Selumbung melalui awig-awig atau perarem sehingga imitasi budaya tidak akan mengganggu tatanan budaya asli setempat (komersialisasi dan komodifikasi budaya dalam konteks pariwisata).

e) Memanfaatkan pecalang (polisi adat) untuk menjaga keamanan dan ketertiban di setiap daya tarik wisata yang terdapat di Desa Selumbung.

f) Memanfaatkan pihak dari luar desa untuk membantu pengembangan sumber daya pariwisata yang dimiliki, baik dari pemerintah kabupaten, pihak swasta seperti biro perjalanan wisata, praktisi ataupun akademisi.

3) Strategi W-O, yaitu mendukung strategi turn-around. Strategi yang digunakan adalah meminimalkan masalah-masalah internal perusahaan sehingga dapat merebut peluang pasar yang lebih baik, dengan cara:

a) Meningkatkan pengetahuan dan kompetensi masyarakat dalam bidang pariwisata, khususnya pelatihan/pembinaan kepada Pokdarwis tentang budaya pasar, karakteristik wisatawan, pemahaman terhadap budaya lokal, dan bahasa, dengan cara berkerja sama dengan pihak pemerintah kabupaten, pihak swasta, praktisi ataupun akademisi.

b) Meningkatkan kerjasama dengan pihak-pihak swasta khususnya dalam hal pengelolaan sampah, pembentukan standarisasi pembangunan dan pelayanan, serta perbaikan jaringan komunikasi.

c) Melakukan pemasaran yang konsisten dan bertanggung jawab dengan melibatkan semua pemangku kepentingan (pemerintah, swasta dan masyarakat lokal). Untuk menjaga konsistensi dan sebagai bentuk pertanggungjawaban atas pengembangan/pemasaran yang dilakukan, maka dapat dibentuk kelompok/organisasi pengawas kegiatan wisata desa. 
4) Strategi W-T, yaitu mendukung strategi defensif. Strategi yang digunakan adalah berusaha untuk meminimalkan kelemahan yang ada serta menghindari ancaman, dengan cara:

a) Meningkatkan sistem pengelolaan pariwisata desa melalui pembentukan regulasi (desa adat dan dinas) yang jelas, sehingga eksploitasi budaya (komersialisasi/komodifikasi budaya dalam konteks pariwisata) yang berlebihan dapat dihindari.

b) Pemerintah, pihak swasta, praktisi ataupun akademisi secara berkelanjutan memberikan pelatihan dan pembinaan kepada Pokdarwis dan masyarakat setempat untuk dapat meningkatkan kompetensi keahlian masyarakat dalam mengelola sumber daya pariwisata yang dimiliki.

c) Menghidupkan kembali kelompok-kelompok seni yang dimiliki oleh Desa Selumbung guna mendukung pengembangan produk wisata desa yang berbasis budaya, dengan pembentukan aturan adat yang membuat para remaja di Desa Selumbung dapat termotivasi untuk melesatrikan budaya yang dimiliki (aturan tersebut dapat berupa jadwal kegiatan latihan tari dan tabuh yang wajib diikuti, menambahkan tari dan tabuh ke dalam kurikulum sekolah sebagai muatan lokal, membangun sanggar seni, dan mengadakan lombalomba antar desa).

d) Membentuk dan membina organisasi/kelompok pengawas kegiatan wisata yang berada di bawah Pokdarwis untuk menangani koherensi program kegiatan, agenda, pelaksanaan, dan pertanggungjawaban kegiatan wisata (atau dapat ditambahkan ke dalam struktur organisasi Pokdarwis).

Berdasarkan hasil skoring diperoleh gambar sebagai berikut:

\section{Peluang}

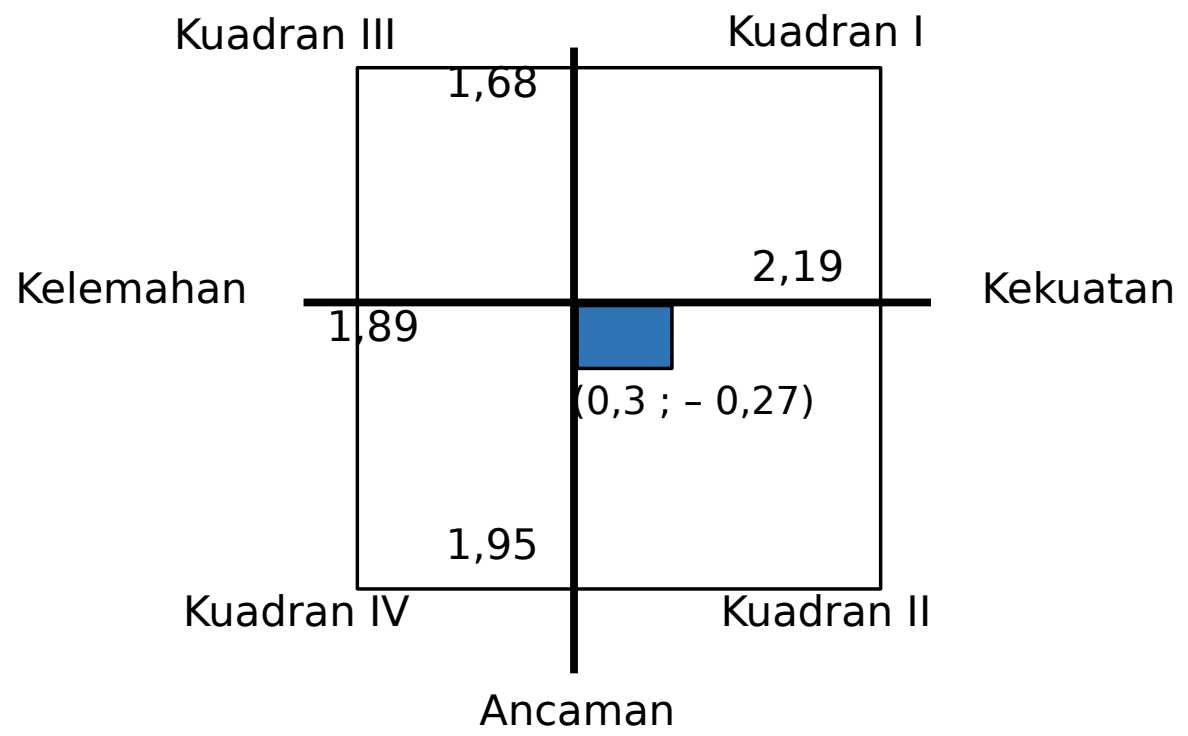

Gambar 3.1: Kuadran analisis SWOT 
Berdasarkan diagram bobot dan rating, Desa Selumbung berada pada kuadran II, yaitu mendukung strategi diversifikasi. Strategi diversifikasi yang diterapkan adalah menggunakan kekuatan yang dimiliki Desa Selumbung untuk memanfaatkan peluang jangka panjang dalam mengembangkan produk wisata berbasis budaya. Strategi pengembangan yang dilakukan dapat dibedakan menjadi tiga, yaitu strategi pengembangan produk, pengelolaan, dan pemasaran.

Dalam usaha mengembangkan Desa Selumbung sebagai desa wisata berbasis budaya dapat diwujudkan dengan cara mengembangkan produk wisata yang telah ada dan mengembangkan produk baru yang masih memiliki keterkaitan dengan produk sebelumnya. Produk yang sudah ada dapat dikemas ke dalam paket-paket wisata yang lebih menarik, disusun ke dalam daftar event budaya (calendar of event), pembuatan paket wisata trekking dan cycling, serta perancangan aktifitas bersama masyarakat (living with local community).

Pertama, penyusunan calendar of event dengan memanfaatkan kegiatan ritual keagamaan yang ada di Desa Selumbung, seperti Upacara Ngusaba Puseh yang dilaksanakan setiap sasih Katiga, Kapat, atau Kalima dan Upacara Mesegeh sebagai event budaya tahunan. Selain itu, kegiatan pementasan Wayang Wong yang dilaksanakan setiap 210 hari sekali yaitu pada Anggarakasih Prangbakat (penanggalan Hindu Bali) juga dapat dijadikan sebagai event budaya yang menarik.

Kedua, yaitu pembuatan paket wisata Trekking dan Cycling dengan memanfaatkan lingkungan Desa Selumbung yang asri sebagai jalur trekking atau cycling.

Jalur trekking dapat ditempuh selama dua sampai tiga jam dan satu jam untuk cycling. Cycling dapat dilakukan dengan starting point di Candidasa atau Buitan menuju Desa Selumbung. Wisatawan dapat memilih untuk bersepeda mengelilingi desa atau berhenti untuk mengamati aktifitas yang disediakan oleh masyarakat.

Ketiga, yaitu pembuatan paket wisata living with Local Community (cooking class, bertani/kebun/menanam tanaman upakara/obat, membuat banten). Masyarakat dapat memanfaatkan aktifitas keseharian masyarakat dan mengemasnya menjadi aktifitas yang bisa diikuti oleh wisatawan, yaitu memasak, bertani/berkebun, dan membuat banten. Kegiatan memasak dilakukan di rumah warga dengan menu masakan tradisional seperti pepes pisang batu, lawar nyawan, dan jaje taluh penyu. Untuk kegiatan bertani/berkebun, wisatawan dapat diarahkan ke sawah atau perkebunan milik warga.

Untuk dapat melaksanakan aktivitas ini, maka masyarakat Desa Selumbung memerlukan pelatihan ketrampilan memandu (guiding) dan berbahasa Inggris (mengantisipasi datangnya wisatawan mancanegara). Selain itu, pengelola dapat mengembangkan produk wisata di Desa Selumbung dengan menciptakan brand atau merek yang sesuai dengan target pasar yang diinginkan. Misalnya dengan memberikan label pada produk madu, tuak, dan pengembangan motif tenun. Pengelola juga dapat menciptakan pengalaman yang berbeda kepada wisatawan dengan welcome drink yang khas. Misalnya sirup bunga kembang sepatu (Hibiscus rosa sinensis). Kembang sepatu dapat dimanfaatkan sebagai welcome drink, karena banyak tumbuh di Desa Selumbung dan cara pengolahannya sederhana. Bunga kembang sepatu juga memiliki keterkaitan dengan aktifitas 
keagamaan (Hindu) bagi masyarakat di Karangasem, sehingga sirup bunga kembang sepatu dapat dikategorikan sebagai produk wisata berbasis budaya, sesuai dengan filosofi yang dimiliki.

Dalam pengelolaan, setiap elemen pemangku kepentingan harus dapat berkoordinasi dengan baik. Masyarakat sebagai tuan rumah (host) harus bisa memberikan pelayanan yang terbaik. Cara yang dapat dilakukan adalah dengan membentuk sistem pengelolaan aktifitas. Sistem ini meliputi penyambutan wisatawan yang datang oleh masyarakat, pembayaran tiket masuk, pemilihan paket wisata yang diinginkan, pemanduan wisata, dan peluang untuk memberikan umpan balik (feedback) oleh wisatawan.

Pertama, wisatawan yang datang akan diarahkan untuk menuju Kantor Sekretariat Pokdarwis (pusat informasi wisata). Kantor Pokdarwis dipilih karena lokasinya strategis, terletak di tengah desa dan di seberang lapangan desa yang dapat digunakan sebagai area parkir. Untuk memudahkan wisatawan, maka perlu dibuatkan petunjuk arah yang jelas, mulai dari jalan utama Denpasar-Karangasem menuju Desa Selumbung dan mengarahkan wisatawan untuk menuju Kantor Pokdarwis.

Pokdarwis sebagai pengelola sumber daya pariwisata desa saat ini perlu membuat aturan mengenai pembangunan fasilitas wisata serta pembagian retribusi yang disesuaikan dengan awig-awig desa setempat. Pokdarwis perlu mendata jumlah homestay dan jenis aktifitas yang dapat diikuti oleh wisatawan, membuat rencana jangka menengah secara tertulis dan diketahui oleh pihak desa adat dan desa dinas, melibatkan perwakilan masyarakat dari masing-masing banjar dalam pengambilan keputusan, serta melakukan rapat terbuka terkait kemajuan ataupun hambatan yang dialami selama proses pengembangan.

Pokdarwis perlu melakukan kerja sama dengan desa dalam mendatangkan praktisi atau akademisi untuk menghidupkan kembali kelompok-kelompok seni yang ada di masyarakat, dengan mewajibkan adanya ekstrakulikuler di setiap sekolah mengenai budaya lokal (tari dan tabuh) untuk meningkatkan pengetahuan dan kecintaan generasi muda terhadap sejarah dan budaya yang berada di Desa Selumbung. Pemerintah kabupaten secara berkelanjutan memberikan pelatihan/pembinaan kepada masyarakat dengan mengajak praktisi ataupun akademisi terkait pengetahuan tentang pariwisata, budaya pasar, pemahaman budaya lokal, dan keahlian berbahasa.

Untuk memudahkan tugas dan tanggung jawab Pokdarwis sebagai pengelola sumber daya pariwisata desa maka pembuatan buku panduan wisatawan (guide book) dan buku panduan pengelola sangat diperlukan.

Sebelum melakukan pemasaran, yang perlu diperhatikan adalah kesiapan produk dan kesiapan sumber daya (manusia dan modal). Di samping itu, juga diperlukan modifikasi produk-produk lama untuk dapat menyesuaikan dengan kebutuhan pasar yang cenderung berubah-berubah. Sehingga perlu dilakukan segmentasi pasar (segmenting), penentuan target pasar (targeting), dan posisi pasar (positioning).

Segmentasi pasar dilakukan melalui identifikasi karakteristik wisatawan berdasarkan demografi, psikografi, dan geografinya. Wisatawan yang memiliki peluang cukup besar untuk berkunjung ke Desa Selumbung adalah kelompok pria 
ataupun wanita dewasa (usia 18 sampai dengan 45 tahun), yang memiliki daya beli cukup tinggi (karena produk seperti tenun, VCO, dan madu harganya cukup tinggi), dan menyukai karakteristik budaya masyarakat tradisional Bali yang erat kaitannya dengan ritual adat/keagamaan.

Sehingga dapat diidentifikasi bahwa taget pasar yang tepat untuk Desa Selumbung adalah wisatawan asal Eropa (khususnya Perancis, Belanda, Jerman) dan Amerika. Wisatawan asal Eropa dan Amerika dipilih karena karakteristik mereka yang cenderung tertarik pada kebudayaan tradisional, pranata sosial, tarian drama, musik, seni, upacara adat dan keagamaan serta nuansa pedesaan, suka mencoba pengalaman dan aktivitas baru (cenderung berpetualang), suka berbelanja kerajinan tangan dan barang-barang antik. Dengan demikian, untuk menciptakan posisi/citra Desa Selumbung di mata wisatawan perlu dilakukan promosi yang berkelanjutan dengan tidak hanya menonjolkan atraksi alam, tetapi juga atraksi budaya khususnya aktifitas keseharian masyarakat dan barang kerajinan tangan sebagai destination image dari Desa Selumbung.

Untuk meningkatkan promosi pariwisata khususnya produk wisata berbasis budaya di Desa Selumbung, diperlukan koordinasi dengan stakeholder terkait menyusun program-program pemasaran pariwisata secara terpadu, dirancang bersama dengan seluruh elemen pemangku kepentingan serta meningkatkan kerjasama dengan pihak travel agent, lembaga pendidikan, maupun promosi di media sosial seperti instagram, facebook, dan youtube. Koordinasi tersebut harus dimulai dari Pokdarwis sebagai pengelola, merancang, menyusun, dan mendistribusikan proposal kerjasama kepada pihak-pihak luar seperti pemerintah ataupun perusahaan swasta (misalnya biro perjalanan dan perhotelan).

\section{Simpulan}

Desa Selumbung memiliki peluang untuk mengembangkan produk wisata berbasis budaya. Produk wisata tersebut berupa rangkaian aktivitas pariwisata yang dapat dikemas ke dalam paket wisata. Aktivitas wisata berbasis budaya di Desa Selumbung terdiri dari aktifitas trekking, menenun, memanen madu, memanen air nira aren (tuak), menanam pohon, menganyam, mengukir, membuat patung tanah liat, menari, melihat aktifitas keagamaan, cooking class, dan sightseeing.

Strategi diversifikasi merupakan strategi dengan memanfaatkan kekuatan untuk merebut peluang dalam pengembangan produk wisata, menciptakan produk baru, dan pendistribusian produk (pemasaran). Adapun strategi pengembangan Desa Selumbung sebagai desa wisata berbasis budaya dapat dilakukan dengan memperhatikan tiga aspek, yaitu aspek pengembangan produk, pengelolaan, dan pemasaran. Dari sisi pengembangan dan pengelolaan produk, Pokdarwis harus konsisten dalam mengorganisasikan dan melaksanakan program-program yang telah direncanakan, dengan tetap melibatkan masyarakat desa secara aktif. Untuk menjaga konsistensi program tersebut, Pokdarwis memerlukan adanya pihak yang mengawasi kinerja mereka, yaitu melalui pembentukan kelompok atau organisasi pengawas pengembangan kepariwisataan desa. Dalam hal pemasaran, dengan cara mengoptimalkan pemanfaatan teknologi (media sosial) untuk membentuk destination image Desa Selumbung sebagai desa wisata berbasis budaya dan 
memperluas kerjasama dengan pihak luar desa (pemerintah dan swasta) untuk mendatangkan wisatawan sesuai target pasar yang diinginkan.

Berdasarkan hasil penelitian, maka dapat disarankan bahwa dalam pengembangan pariwisata berbasis budaya di desa Selumbung dibutuhkan koordinasi dan kerjasama seluruh stakeholder pariwisata (pemerintah, swasta, perguruan tinggi, lembaga swadaya masyarakat) dalam setiap pelaksanaan program pemberdayaannya.

\section{Daftar Pustaka}

Buhalis, D. 2000. Marketing the Competitive Destination of the Future. Tourism Management, 21 (1): 97-116.

Desa Selumbung. 2017. Buku Profil Desa Selumbung 2017. Karangasem.

Dinas Kebudayaan dan Pariwisata Kabupaten Karangasem. 2016. Buku Kepariwisataan Kabupaten Karangasem Tentang Perolehan Pendapatan Asli Daerah Karangasem. Amlapura.

Muljadi, A.J. 2009. Kepariwisataan dan Perjalanan. PT Raja Grafindo Persada. Jakarta.

Prasiasa, Putu Oka. 2011. Destinasi Pariwisata Berbasis Masyarakat. Selemba Empat. Jakarta.

Sugiyono. 2003. Metode Penelitian Kuantitatif, Kualitatif dan R\&D. Alfabeta. Bandung.

Sunaryo. 2013. Kebijakan Pembangunan Destinasi Pariwisata, Konsep dan Aplikasinya. Gava Media. Yogyakarta.

Rangkuti, Freddy. 2017. Analisis SWOT-Teknik Membedah Kasus Bisnis. PT Gramedia Pustaka Utama. Jakarta. 